\title{
Preparation and Microstructure Characteristics of Aluminium 6061 Alloy Based Metal Matrix Composite
}

\author{
Sathiyaraj S ,Vijayakumar K, Adarsh P K, Aswin N, Mohamed Asiq
}

\begin{abstract}
The role of engineering substances within the improvement of cutting-edge era like metallic Matrix Composites (MMCs) have evoked a eager hobby nowadays for capacity programs in aerospace and car industries as a result of their advanced power. Aluminium (6061) and Boron Carbide (Powder) is chosen for reinforcement material and matrix respectively. $\mathrm{Al}-\mathrm{B} 4 \mathrm{C}$ composites containing special weight probabilities $3.5 \%, 7.0 \%$ and $10.5 \%$ of $B 4 C$ have been fabricated by way of stir casting Technique. Experiments are conducted with the aid of various weight fraction of $\mathrm{B} 4 \mathrm{C}(3.5 \%, 7.0 \%$ and $10.5 \%)$, at the same time as maintaining all other parameters regular. The compositions of their small structural options are determined through scientific discipline magnifier..
\end{abstract}

Keywords : About Boron Carbide, Stir casting, Aluminium and metal Matrix Composite.

\section{INTRODUCTION}

$\mathrm{T}_{\mathrm{h}}$ he chemically awesome level which is fabric inclusive is known as composite fabric[1]. The matrix or non-stop element has the reinforcing aspect which is present inside. The matrix which is metallic is known as the Metal Matrix Composite (MMC)[2]. The reinforcement takes place in MMC by means of non-stop, quick fibers, whiskers and particles.Now days with the fashionable development, superior manufacturing materials innovations for varied manufacturing packages are continuing to grow [3].Steel matrix composite is one in every effective delivery to meet these desires. Composite fabric is one of the most robust alternatives[4]. Compounds in composites are mixed in this way so we can make better use of their figure fabric while minimizing the outcomes of their deficiencies to a certain extent[5]-[6].

\section{OBJECTIVES OF THE PROJECT}

The targets of the challenge are:

Revised Manuscript Received on December 16, 2019

* Correspondence Author

Sathiyaraj.S *, Mechanical Department, Aarupadai Veedu Institute Of Technology, Vinayaka Mission's Research Foundation, Deemed To Be University, Chennai,India. Email: sathiyaraj@avit.ac.in,

K.Vijayakumar, Mechanical Department, AarupadaiVeedu Institute Of Technology, Vinayaka Mission's Research Foundation, Deemed To Be University. chennai, India. Email: vijayakumar@avit.ac.in,chennai,India.

Adarsh P K,N Aswin, Mohamed Asiq, Mechanical Department, AarupadaiVeedu Institute Of Technology, Vinayaka Mission's Research Foundation, Deemed To Be University, Chennai, India.
The primary objective of this paper is to manufacture Al-B4C metal matrix composite with varying composition (three. $5 \%, 7.0 \%$, and $10 \%$ ) of Boron Carbide reinforcement debris that used the stir casting approach

The compositions of their micro structural capabilities have been determined by using Metallurgical Microscope.

\section{CHOICE OF MATRIX}

\section{A. Aluminium 6061}

Define The Al 6061 commercial grade has $2.7 \mathrm{~g} / \mathrm{cm} 3$ theoretical density and used for the metal matrix such as, marine, aerospace and transport applications and with the welding strength, efficiency and high corrosion resistance. Aluminium 6061 matrix is shown in figure 1. The constitu $\neg$ ents of $\mathrm{Al} 6061$ have been given in Table I.

Table- I: Name of the Table that justify the values

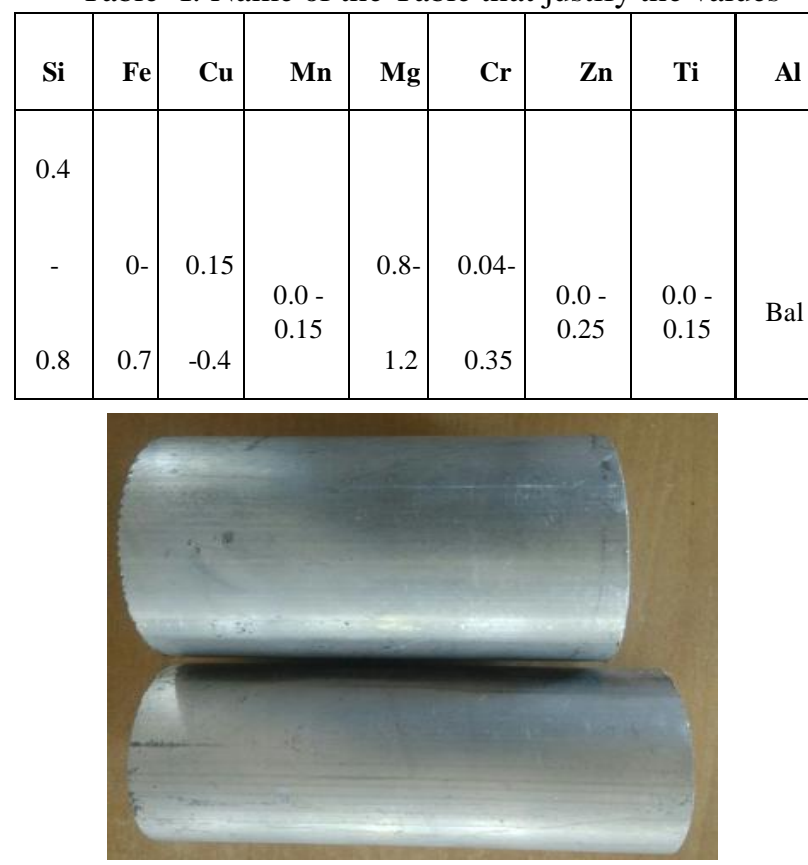

Fig. 1. Aluminium 6061 Matrix .

\section{B. Boron Carbide}

The hardest ceramic material known as boron carbide is taken as reinforcing

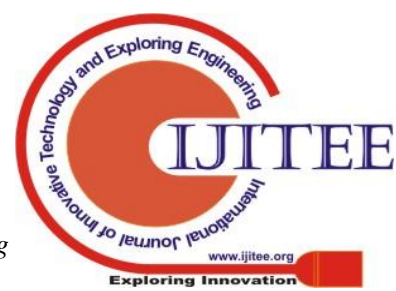




\section{Preparation And Microstructure Analysis Of Aluminum 6061AlloyBased Metal Matrix Composite}

material. The B4Cis $2.52 \mathrm{~g} / \mathrm{cm} 3$ density and its melting point is $2450^{\circ} \mathrm{C}$. B4C as shown in figure 2. The constitu-nents of $\mathrm{B} 4 \mathrm{C}$ have been given in Table II.

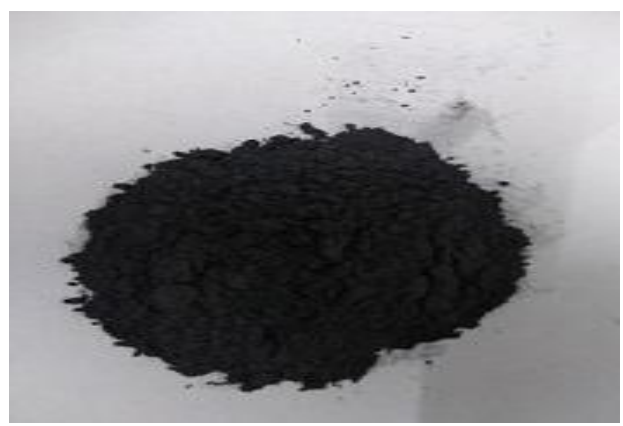

Fig. 2.Boron Carbide Powder .

Table- II: Constituents of Boron Carbide

\begin{tabular}{|l|c|c|c|c|c|c|}
\hline Elements & $\mathrm{B}+\mathrm{C}$ & $\begin{array}{c}\mathrm{B} \\
\mathrm{Min}\end{array}$ & $\begin{array}{c}\mathrm{C} \\
\mathrm{ma} \\
\mathrm{x}\end{array}$ & $\mathrm{B}_{2} \mathrm{O}_{3}$ & $\mathrm{Fe}$ & $\mathrm{Si}$ \\
\hline Percentage & $\begin{array}{c}94-98 \\
5\end{array}$ & $74-79$ & $17-24$ & $0.1-1.0$ & $0.2-0.5$ & $0.1-0.3$ \\
\hline
\end{tabular}

\section{METHODS AND MATERIALS}

Because For the manufacturer of $\mathrm{Al} \mathrm{MMC}$, stir casting method was identified as well as the marking were given in Table III.Using coupling motor with gearbox and a mild steel stirrer, the preliminary stirring device were superior. All the melting was accomplished in an oil-fired furnace in a graphite crucible. Bars of aluminum 6061 were preheated at one thousand for three to 4 hours in advance than melting and mixing the Silicon Carbide debris had been preheated at $500^{\circ}$.

The semi-strong kingdom is preserved by the melted alloys and cooled down as liquid. The composite slurry is exactly become reheated after the completion of manual blending. The mechanical mixing is changed for 10 minutes at regular string at $700 \mathrm{rpm}$. The modified temperature controlled inside is $760^{\circ} \mathrm{C}$ in the final blending system. The die mould is prepared with the scale for $(100 \mathrm{~mm} \times 100 \mathrm{~mm} \times 14 \mathrm{~mm})$ for composite slurry pouring. The squeeze and stir casting is used as the experimental setup. The low charge liquid has to provide the MMC for stir casting approach, so the stir preprocessing is discussed in this paper. Figure 3 and 4 desk shows the stir casting setup to examine the flexible, attractive and simple.

It produces a undamaged reinforced materials over the stir casting direction guarantees. Additionally fabricates Al-B4C MMCs specimen as shown in determine in figure 5.

Table- III: Compositions of samples

Sample of weight $=1250$ Grams

\begin{tabular}{|c|l|l|l|}
\hline Sample No & $\begin{array}{l}\text { Aluminium } \\
\text { (Grams) }\end{array}$ & Boron Carbide(Grams) & Remarks \\
\hline 1 & 1206.25 & 43.75 & Al-3.5\%B4C \\
\hline 2 & 1162.50 & 87.50 & Al-7.0\%B4C \\
\hline 3 & 1118.75 & 131.25 & Al-10.5\%B4C \\
\hline
\end{tabular}

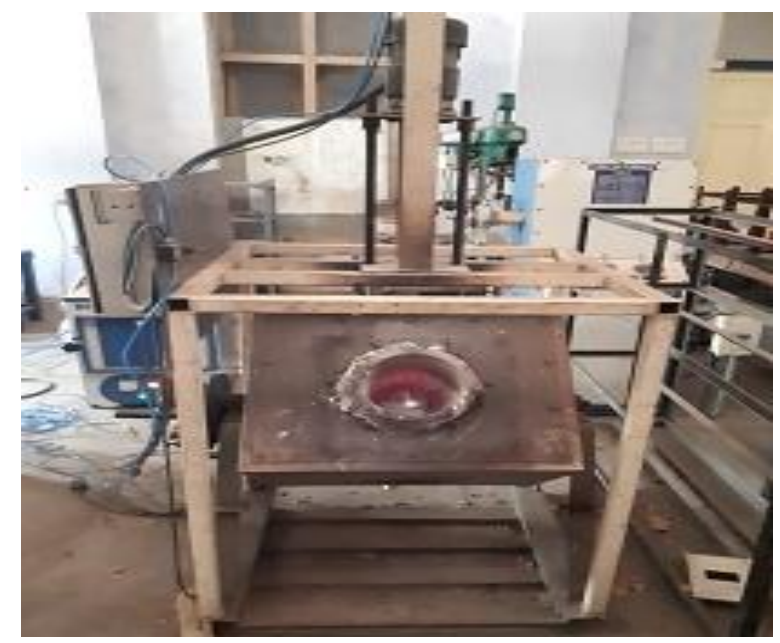

Fig. 3.Stir Casting Apparatus .

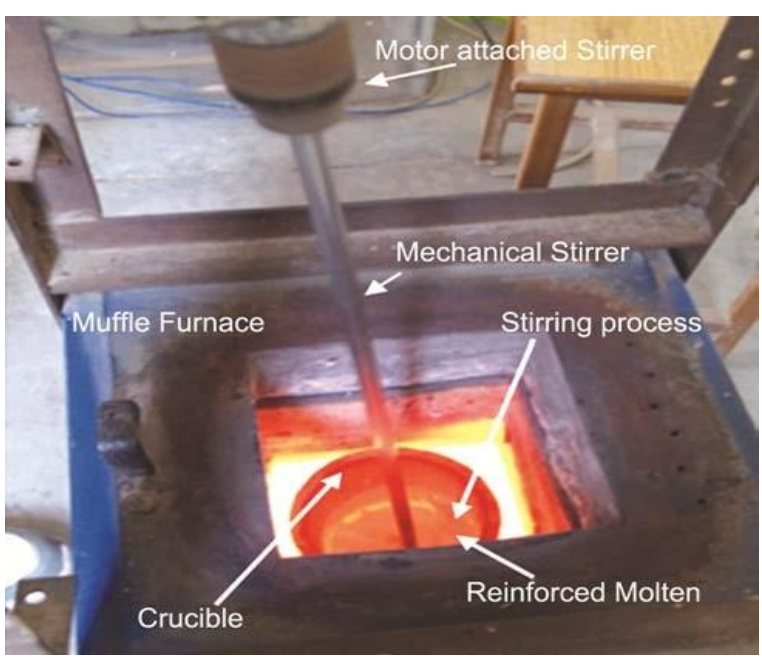

Fig. 4.Stir Casting process .

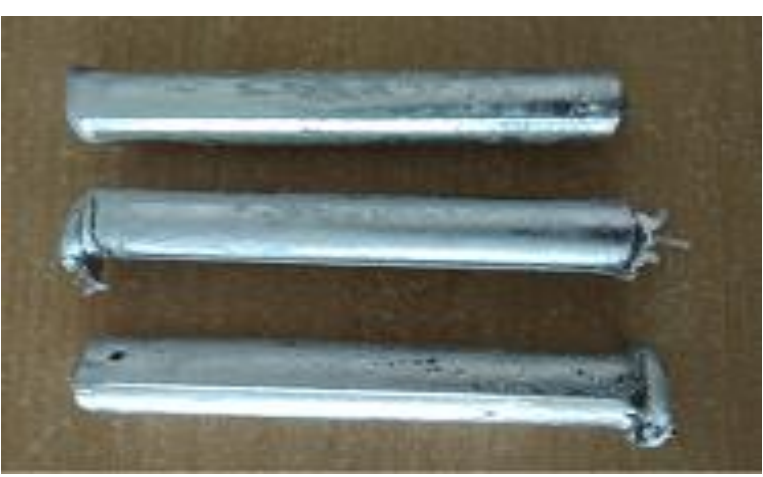

Fig. 5.Al-B4C MMCs Specimen .

Published By:

Blue Eyes Intelligence Engineering \& Sciences Publication 


\section{RESULT AND DISCUSSION}

Boron Carbide with aluminium is fabricated by using stir casting process for particulate composites. Al-B4C MMCs are proven in determine in figure 7,8 and 9. Metallurgical Microscope Dewinter Tech equipment as proven figure 6.

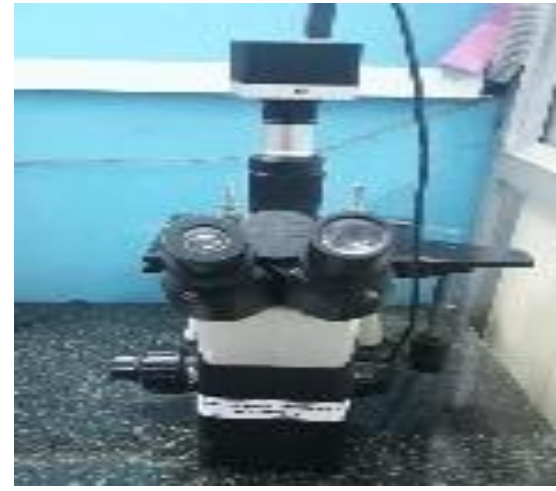

Fig. 6. Metallurgical Microscope Dewinter Tech Equipment.

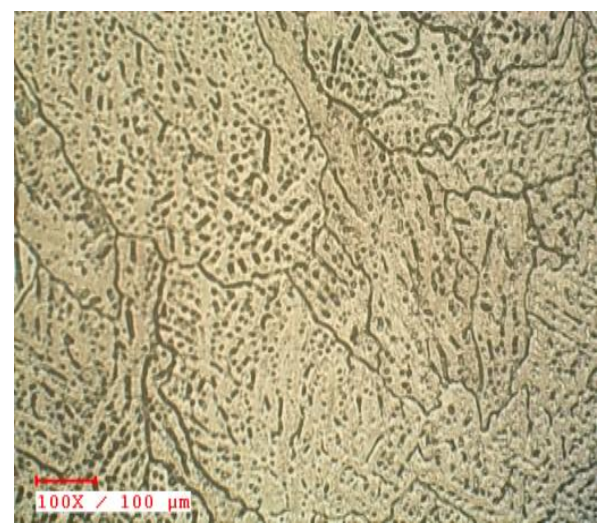

Fig. 7. Microstructure of Al-3.5\% B4C MMCs.

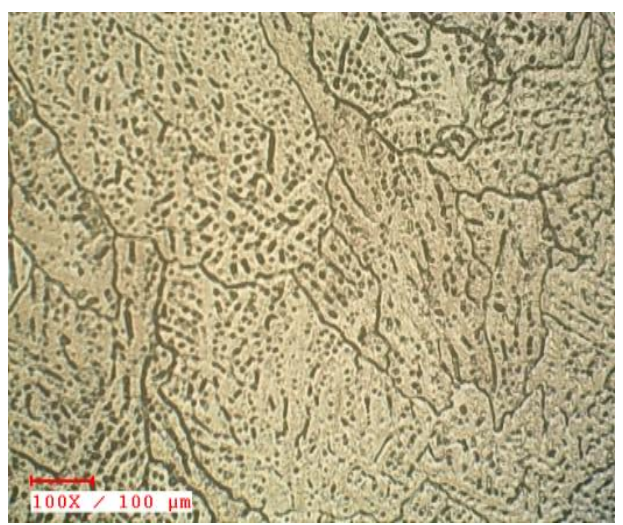

Fig. 8. Microstructure of Al-7.0\% B4C MMCs.

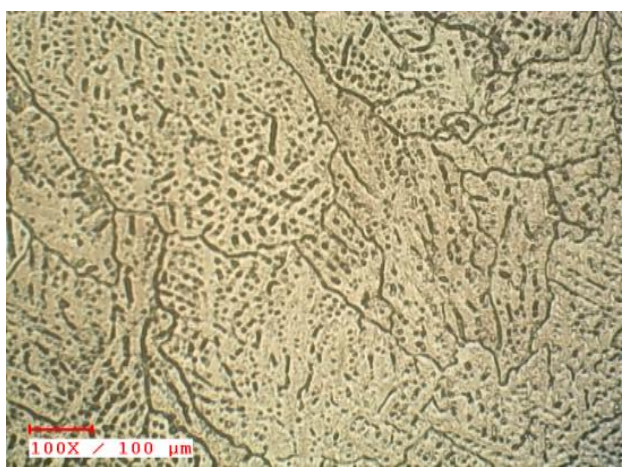

Fig. 9. Microstructure of Al-10.5 \% B4C MMCs.
Chemical composition of the composite of $3.5 \% \mathrm{wt}, 7.0$ $\%$ wt and $10.5 \%$ wt Al-B4C is discussed in Table IV.

Table- IV: Chemical composition

\begin{tabular}{|l|c|c|c|}
\hline Composition & $\begin{array}{c}\mathrm{Al}-3.5 \% \mathrm{~B} 4 \\
\mathrm{C}\end{array}$ & $\begin{array}{c}\mathrm{Al}-7.0 \% \mathrm{~B} 4 \\
\mathrm{C}\end{array}$ & $\begin{array}{c}\mathrm{Al}-10.5 \% \mathrm{~B} 4 \\
\mathrm{C}\end{array}$ \\
\hline Silicon & 0.789 & 0.790 & 0.523 \\
\hline Iron & 0.300 & 0.688 & 0.339 \\
\hline Copper & 0.269 & 0.187 & 0.095 \\
\hline Manganse & 0.126 & 0.099 & 0.094 \\
\hline Mangesium & 0.828 & 0.817 & 0.526 \\
\hline Chromium & 0.128 & 0.246 & 0.092 \\
\hline Zinc & 0.024 & 0.009 & 0.021 \\
\hline Titanium & 0.027 & 0.027 & 0.005 \\
\hline Boron & 0.001 & 0.002 & 0.006 \\
\hline Aluminium & Balance & Balance & Balance \\
\hline
\end{tabular}

\section{CONCLUSION}

B4C MMCs were produced through stir casting route with extraordinary wt\%(viz.,3.5,7.0\& $10.5 \mathrm{wt} \%$ ) of the microstructure and reinforcement properties are performed and evaluated. The following conclusions are made from this study.

The Al-Boron carbide has the production and it is changed efficiently.

The microstructure of Al-B4C MMCs was discovered to be Boron are uniformly dispersed particles with a aluminium matrix wt\% of reinforcement.

\section{REFERENCES}

1. N. Khan ,M. Wahid ,S. Singh, A. Siddiquee, Z. Khan," A study on micro hardness in wire electrical discharge machining based on taguchi method", Int. J. Mech. Produc. Eng. Vol.1,No.1,2013,pp.10-5.

2. R. G. Bhandare ,P. M. Sonawane ," Preparation of aluminium matrix composite by using stir casting method", International Journal of Engineering and Advanced Technology,Vol.3.No.3,Dec.2013 Dec,pp.61-5.

3. R. Dasgupta ,H. Meenai," SiC particulate dispersed composites of an $\mathrm{Al}-\mathrm{Zn}-\mathrm{Mg}-\mathrm{Cu}$ alloy: Property comparison with parent alloy", Materials characterization,Vol.54,No.4-5, May.2005,pp.438-45.

4. J. Jeykrishnan,B. V. Ramnath,X. H. Savariraj, R. D. Prakash,V. D. Rajan, D. D. Kumar," Investigation on tensile and impact behavior of aluminum base silicon carbide metal matrix composites", Indian journal of science and technology, Vol.37,No.9, oct.2016.

5. B. Ravi ," Fabrication and mechanical properties of Al7075-SiC-TiC hybrid metal matrix composites", International Journal of Engineering Science Invention, Vol.6,2017,pp.12-9.

6. A.Aravindkumar," CFD ANALYSIS OF GAS FLOW BEHAVIOR IN VARIOUS ECONOMIZER DUCT", International Journal of MC Square Scientific Research ,Vol.6, No.1 Nov 2014,pp.61-65

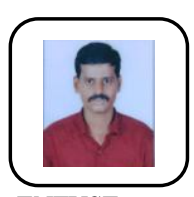

ENFUSE.

\section{AUTHORS PROFILE}

Sathiyaraj.S, Assistant Professor, Mechanical Department Aarupadai Veedu Institute of Technology, Vinayaka Mission's Research Foundation, Deemed To Be University. Having 10 years of experience. Life member in ISTE and

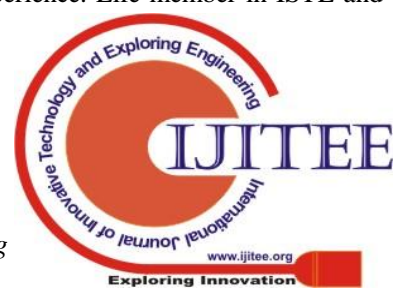




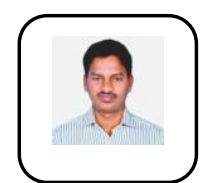

K.Vijayakumar, Asst. Professor , Department of Mechanical Engineering, Aarupadai Veedu Institute of Technology, Vinayaka Mission Research Foundation, Deemed To Be University. Having 10 years of experience. Life member in ISTE .and ENFUSE.

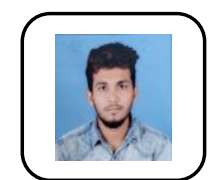

Adarsh $\mathbf{P}$ K ,UG Student Mechanical Department, Aarupadai Veedu Institute Of Technology, Vinayaka Mission's Research Foundation, Deemed To Be University.

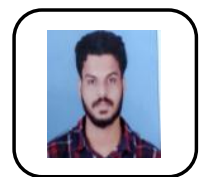

N Aswin, UG StudentMechanical Department, Aarupadai Veedu Institute Of Technology, Vinayaka Mission's Research Foundation, Deemed To Be University.

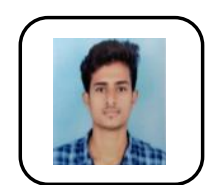

Mohamed Asiq,UG Student Mechanical Department, AarupadaiVeedu Institute Of Technology, Vinayaka Mission's Research Foundation, Deemed To Be University 